Andrea Vaona, Roberto Patuelli

New empirical evidence on local financial development and growth

Quaderno N. 08-05

Decanato della Facoltà di Scienze economiche Via G. Buffi, $13 \mathrm{CH}-6900$ Lugano 


\title{
New empirical evidence on local financial development and growth ${ }^{\S}$
}

\author{
Andrea Vaona ${ }^{\mathrm{a}, \mathrm{b}, \mathrm{c}, *}$ and Roberto Patuelli ${ }^{\mathrm{a}}$ \\ ${ }^{a}$ Institute for Economic Research (IRE), University of Lugano (USI), Switzerland \\ ${ }^{b}$ Kiel Institute for the World Economy, Kiel, Germany \\ "University of Verona, Italy
}

This draft: 13 May 2008

s The authors would like to thank Alessandra Guariglia and David Roodman for help with the Stata module xtabond2. Andrea Vaona gratefully acknowledges financial support from the Italian National Research Council. The usual disclaimer applies.

* Corresponding author: Andrea Vaona, Institute for Economic Research (IRE), University of Lugano (USI), Via Maderno 24, CP 4361, CH-6904 Lugano (Switzerland); Email: andrea.vaona@lu.unisi.ch. 


\title{
New empirical evidence on local financial development and growth
}

\begin{abstract}
In this paper, we show that the regional finance-growth nexus in Italy is robust to a series of innovations with respect to the existing literature on the topic. We use finer measures of economic and financial development, as well as instruments with a deeper economic content. We rely on state-of-the-art cross-sectional and panel estimation methods, and we offer a thorough investigation of the nonlinearities in the relation between finance and growth. Our results show that, while local financial development is a key factor for economic growth, in regions with inefficient courts more credit might translate into reduced growth due to opportunistic behaviour and the consequent misallocation of funds.
\end{abstract}

Jel codes: O18, O16, C31.

Keywords: Finance, Growth, Regions, Italy, Cross-Section Analysis, Panel Data Analysis. 


\section{Background}

Since the groundbreaking contributions of King and Levine (1993a,b), economists have shown renewed interest in the finance-growth nexus. Results have often been conflicting across studies using a variety of indicators for financial development, different econometric methods, model specifications, and datasets. In this regard, a thorough review is offered by Levine (2004).

Focusing on cross-country studies using measures of financial development connected to the banking sector, Levine (1998), Levine et al. (2000) and Beck et al. (2000) designed an innovative research strategy. In order to overcome possible biases deriving either from the endogeneity of financial development indicators within a growth regression, or from the omission of possible relevant variables, they took two steps. In the first step, they resorted to the following model within a cross-sectional framework

$$
G=\alpha+\beta F+\gamma X+\varepsilon,
$$

where: $G$ was either per capita GDP growth, or growth of capital stock per head, or productivity growth; $F$ was different financial development indicators; $X$ was a set of controls (income per capita, education, political stability, indicators of exchange rate developments, international trade, fiscal and monetary policy); $\alpha, \beta$ and $\gamma$ were coefficients; and $\varepsilon$ was the stochastic error. $F$ was instrumented by indicators of origin of the legal system, which, according to the literature, affects the letter and the enforcement of national credit laws, protecting external investors and promoting financial development to different extents.

In the second step, they resorted to dynamic panel models, with the following specification

$$
y_{i, t}=\alpha y_{i, t-1}+\beta^{\prime} Z_{i, t}+\eta_{i}+\varepsilon_{i, t},
$$

where: $y_{i, t}$ was the log of real per capita GDP at time $t$ in country $i ; Z_{i, t}$ was a set of controls including financial indicators; $\eta_{i}$ was an unobserved country-specific effect; and $\varepsilon_{i, t}$ a stochastic error.

However, the earlier promising results of Levine and co-authors need to be qualified, since they rely on a strong assumption: the poolability of countries at different stages of development. This assumption has found scant empirical support in the empirical literature (Arestis et al., 2004, Rioja and Valev, 2004, Loyaza and Ranciere, 2005, Apergis et al., 2007, Schiavo and Vaona, 2007).

As a matter of consequence, Vaona (2008a), using Italian data, proposed to apply the research strategy designed by Levine and co-authors to a regional setting, where poolability is supported by statistical tests. In this context, financial development can have an impact on local growth due to market segmentation (Guiso et al., 2004a).

To this purpose, an Italian dataset appears particularly interesting, given the intensive monitoring activity implemented by the Bank of Italy on local credit market conditions, and given the considerable 
attention that the international literature has devoted to Italian regions so far (Lucchetti et al., 2001; Guiso et al., 2004a, b, 2006; Usai and Vannini, 2005; Jappelli et al., 2005).

In order to show the robustness of our results, we follow the setup of Vaona (2008a), using a sample of Italian NUTS-3 regions, performing both cross-section and dynamic panel estimations, and controlling for endogeneity, spatial unobserved heterogeneity, spatial correlation and poolability. For the dynamic panel estimates we use three-year averages in order to overcome possible distortions deriving from business cycles, and we rely on Roodman (2005).

\section{Model Specification and Innovations of the Paper}

Regarding the model specification, on the one hand, our choices for $G, F$ and $y$ represent one of the elements of novelty of the paper, and are illustrated below. On the other hand, for $X$ and $Z$, we follow Vaona (2008a). For $X$, we use: the number of crimes per head; the number of students attending secondary schools over resident population; the sum of exports and imports over GDP; the expenditure in finished public infrastructures over GDP; and the real GDP pear head. All the variables are taken at the first year of observation, namely 1986. In $Z$, we include: the number of crimes per head; ${ }^{1}$ the number of students attending secondary schools over resident population; and the sum of exports and imports over GDP. We could not include the expenditure in finished public infrastructures, since no relevant data is available after 2000 .

With respect to Vaona (2008a), we introduce four important novelties.

First, the aforementioned study considers, as an indicator of economic development, the growth rate of real per capita value-added in the cross-section estimation, and the level of per capita value-added in the dynamic panel estimation. On the other hand, following Jappelli et al. (2005) and Fabiani and Pellegrini (1997), we use the growth rate and the level of real per capita GDP for $G$ in model (1) and for $y$ in model (2), respectively.

Second, we use a finer measure of financial development. Since Vaona (2008b) showed that credit to households and non-profit organisations, credit to non-financial enterprises with a public structure, and credit to the public administration are not connected to economic growth, we focus here only on credit supplied by private banks to private firms, taking - in a regional setting - a similar step to the one taken by Levine et al. (2000) in the cross-country literature. On the one hand, our measure of financial development is aggregate, so it is not a direct indicator of credit rationing based on micro data, as the one used by Guiso et al. (2004a). On the other hand, its availability for many years makes it possible to show not only cross-sectional but also longitudinal evidence, as in cross-country studies. Furthermore, Jappelli et al. (2005) showed that different measures of financial development in Italian regions tend to show similar geographical patterns.

\footnotetext{
${ }^{1}$ We also included its square term in order to control for possible nonlinear effects of crime on economic growth (see, for the case of Italy, Peri, 2004).
} 
Third, the instruments used by Vaona (2008a) in his cross-section estimation have mainly a statistical nature, being regional dummies not related with future growth, which should capture regional disparities in the efficiency and efficacy of courts within a country. Here, similarly to Jappelli et al. (2005), we consider as instruments two direct measures of efficiency and efficacy of the judiciary system: the length of first instance and appeal civil trials. In particular, we consider both their unweighted sum and the sum weighted by the number of trials in each instance. We do so in order to capture the possible effects of the presence of agents, who discount time in different ways and, therefore, could weight differently the length of first instance and appeal trials. In the instruments set of the dynamic panel data estimator, we include the lags in the levels and in the first differences of logs of the two variables above, as well as of private credit to private firms. Descriptive statistics for all the data are set out in Table 1.

Fourth, and finally, when considering dynamic panel data estimation, we manage to capture the nonlinearities underlying the finance-growth nexus, by fitting to the data a dynamic model of the (log of) real per capita GDP containing a third-order polynomial (in logs) of our indicator of financial development, besides the further controls sketched above. Consistently with Rioja and Valev (2004), we find that the higher is the degree of local financial development, the weaker is its impact on growth. However, consistently with De Gregorio and Guidotti (1995) and Guariglia and Poncet (2007) and similarly to Rioja and Valev (2004), we also find that, in provinces with an inefficient allocation of credit, a higher ratio between credit and local GDP can have a negative impact on growth. Our identification strategy allows us to propose a new explanation of why this might happen. ${ }^{2}$ In regions with a highly inefficient judiciary system, opportunistic behaviour is widespread. Under these conditions, banks fund projects doomed to fail and to absorb more economic resources than their returns. Consequently, the growth rate of local economies may be damaged - rather than benefited by a greater availability of credit.

The following section illustrates our results and concludes.

\section{Results and Conclusions}

Table 1 sets out our cross-sectional results. We group our sample of NUTS-3 provinces according to the NUTS-2 region they belong to. In this way, it is possible to use static panel estimators also in a cross-sectional setting, controlling better for unobserved heterogeneity. First, we fit a random-effects model and a fixed-effects model to the data. A Hausman test points to the latter as the one to be preferred. Subsequently, we drop insignificant regional dummy variables, and we implement a 2-stage least squares dummy variables (2SLSDV) estimation, using the instruments mentioned above. An F test supports our instruments, and the first stage results show that an increase of one day in both the

\footnotetext{
${ }^{2}$ Other possible theoretical justifications for this pattern can be found in Rioja and Valev (2004). They are based on economies of scale, minimum size requirements, and learning-by doing effects in banking.
} 
weighted and un-weighted sums of the length of first instance and appeal civil trials decreases the ratio of private credit to private firms over GDP by 0.13 per cent. ${ }^{3}$ The model is supported also by a test for overidentifying restrictions. Though a Durbin-Wu-Hausman test points to the LSDV estimator as the one to be preferred, in both 2SLSDV and LSDV the main forces driving local economic growth in Italy appear to be financial development and convergence, which is consistent with the findings of Vaona (2008a). Southern regions like Puglia and Campania appear to have specific factors that make them lag behind the rest of the country. No spatial correlation is found in the residuals.

A similar picture emerges when considering panel data estimates (Table 3). Convergence is still a major factor affecting growth, given the significance of the first lag of real per capita GDP. However, the exposure to international markets is important as well, possibly reflecting the consequent better allocation of production factors. As anticipated above, financial development has a highly nonlinear effect on growth. A third-order polynomial in private credit to private firms turns out to be significant at a 5 per cent level. In order to better assess the connection between finance and growth, we simulate the model over the interval between the minimum and maximum values of private credit to private firms over GDP, keeping the significant controls at their average values, and forcing the coefficient of insignificant variables to zero. Figure 1 shows our results. As anticipated in the previous section, finance has a positive - though declining - effect on growth. However, in regions where the judiciary system is inefficient and opportunistic behaviour is more widespread, more finance might translate into less growth, as more resources are inefficiently allocated to poor projects.

In order to assess the poolability of provinces belonging to the South, the Centre, the North-West and the North-East of Italy, we interacted the third-order polynomial in our measure of financial development with dummies for each of the four Italian macro-regions. ${ }^{4} \mathrm{~A}$ Wald test for the equality of the coefficients across macro-regions could not reject the null. All the other specification tests support the model.

Summarizing, in this study we showed that the finance-growth nexus at the regional level in Italy is robust to a series of innovations in the analysis carried out. With respect to previous studies, we used more refined measures of economic growth and financial development. Moreover, we used instruments with a deeper economic content than earlier, and we offered a better assessment of the nonlinearities characterizing the finance-growth nexus. To conclude, the judiciary system is of paramount importance in understanding this economic issue. The more efficient are the courts located in a local economy, the better will its credit market work, and funds will be less likely to be allocated to projects doomed to fail.

\footnotetext{
${ }^{3}$ We compute elasticities at the average value of regressors.

4 A picture of the Italian macro-regions is available in Vaona (2008a).
} 


\section{References}

Apergis, N, Filippidis, I and Economidou, C (2007) Financial Deepening and Economic Growth Linkages: A Panel Data Analysis, Review of World Economics 143(1): 179-198.

Arestis P, Luintel AD and Luintel KB (2004) Does Financial Structure Matter?. Economics Working Paper Archive 399, The Levy Economics Institute.

Beck T, Levine R and Loayza N (2000) Finance and the Sources of Growth, Journal of Financial Economics 58: 261-300.

De Gregorio J and Guidotti P (1995) Financial Development and Economic Growth, World Development 23(3): 433-448.

Fabiani, S and Pellegrini G (1997) Education, Infrastructure, Geography and Growth: An Empirical Analysis of the Development of Italian Provinces. Temi di Discussione, No. 323, Bank of Italy, Rome.

Guariglia, A and Poncet S, (2008) Could Financial Distortions Be No Impediment to Economic Growth After All? Evidence from China, Journal of Comparative Economics (in press).

Guiso L, Sapienza P and Zingales L (2004a) Does Local Financial Development Matter?, Quarterly Journal of Economics 119: 929-969.

Guiso L, Sapienza P and Zingales L (2004b) The Role of Social Capital in Financial Development, American Economic Review 94: 526-556.

Guiso L, Sapienza P and Zingales L (2006) The Cost of Banking Regulation. NBER Working Paper 12501.

Jappelli T, Pagano M and Bianco M (2005) Courts and Banks: Effects of Judicial Enforcement on Credit Markets, Journal of Money, Credit and Banking 37(2): 223-244.

King RG and Levine R (1993a) Finance and Growth: Schumpeter Might Be Right, Quarterly Journal of Economics 108: 717-737.

King RG and Levine R (1993b) Finance, Entrepreneurship, and Growth, Journal of Monetary Economics 32: 513-542.

Levine R (1998) The Legal Environment, Banks, and Long-Run Economic Growth, Journal of Money, Credit, and Banking 30: 596-613.

Levine R, Loayza N and Beck T (2000) Financial Intermediation and Growth: Causality and Causes, Journal of Monetary Economics 46: 31-77.

Loayza, N and Ranciere R (2005) Financial Development, Financial Fragility, and Growth. IMF Working Papers 05/170, International Monetary Fund.

Lucchetti R, Papi L and Zazzaro A (2001) Banks' Inefficiency and Economic Growth: A MicroMacro Approach, Scottish Journal of Political Economy 48(4): 400-424. 
Peri G (2004) Socio-Cultural Variables and Economic Success: Evidence from Italian Provinces 1951-1991, Topics in Macroeconomics 4:1, Article 12.

Rioja F and Valev N (2004) Does One Size Fit All?: A Reexamination of the Finance and Growth Relationship, Journal of Development Economics 74(2): 429-447.

Roodman D (2005) xtabond2: Stata Module to Extend Xtabond Dynamic Panel Data Estimator. Center for Global Development, Washington, Available at: http://econpapers.repec.org/software/ bocbocode/s435901.htm.

Schiavo S and Vaona A (2007) Poolability and the Finance-Growth Nexus: A Cautionary Note, Economics Letters 98(2): 144-147.

Usai S and Vannini M (2005) Banking Structure and Regional Economic Growth: Lessons from Italy, Annals of Regional Science 39: 691-714.

Vaona A (2008a) Regional Evidence on Financial Development, Finance Term Structure and Growth, Empirical Economics 34:1: 185-201.

Vaona A (2008b) Empirical Evidence on the Finance-Growth Nexus at the Regional Level. In: Grönziger G, W Matiaske and K Spiess (eds) Europe and its Regions, Cambridge Scholar Publ., Cambridge (in press).

Figure 1 - The effect of local financial development on real GDP per capita - simulation results

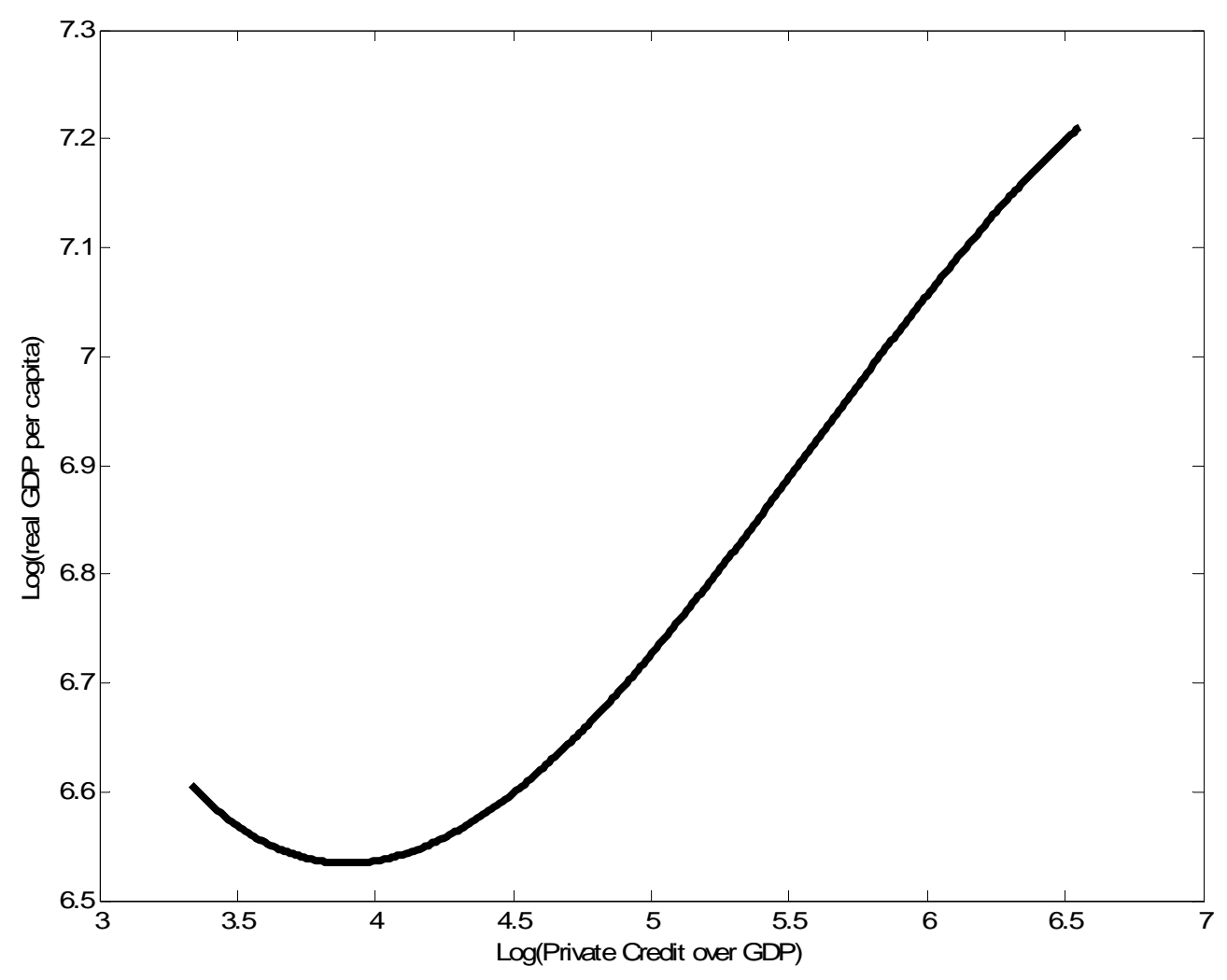


Table 1 - Descriptive statistics

\begin{tabular}{|c|c|c|c|c|c|}
\hline & & Mean & $\begin{array}{l}\text { Standard } \\
\text { Deviation }\end{array}$ & Min. & Max. \\
\hline \multirow{9}{*}{$\begin{array}{l}\text { Cross-section } \\
\text { data }\end{array}$} & $\begin{array}{l}\text { Total percentage growth of } \\
\text { real GDP per head between } \\
1986 \text { and } 2006^{\text {a }}\end{array}$ & 46.67 & 21.06 & -42.04 & 102.63 \\
\hline & $\begin{array}{l}\text { Private credit to private } \\
\text { firms over GDP in } 1986^{\mathrm{b}}\end{array}$ & 225.58 & 73.34 & 69.16 & 410.99 \\
\hline & $\begin{array}{l}\text { Sum of exports and imports } \\
\text { over GDP in } 1986^{b}\end{array}$ & 271.95 & 150.70 & 14.10 & 667.41 \\
\hline & $\begin{array}{l}\text { Value of finished public } \\
\text { infrastructures over GDP in } \\
1986\end{array}$ & 18.19 & 12.80 & 3.49 & 73.04 \\
\hline & $\begin{array}{lr}\text { Students } & \text { attending } \\
\text { secondary } & \text { school over } \\
\text { resident population in } 1986^{c}\end{array}$ & 45.66 & 5.79 & 33.95 & 58.32 \\
\hline & $\begin{array}{l}\text { Real GDP per head in } \\
1986^{a, e}\end{array}$ & 1584.297 & 323.05 & 832 & 2272 \\
\hline & Crimes per head in $1986^{\mathrm{d}}$ & 29.41 & 11.85 & 10.05 & 81.51 \\
\hline & $\begin{array}{l}\text { Un-weighted sum of the } \\
\text { length of first instance and } \\
\text { appeal civil trials in days }\end{array}$ & 718 & 135.791 & 577 & 1243 \\
\hline & $\begin{array}{l}\text { Weighted sum of the length } \\
\text { of first instance and appeal } \\
\text { civil trials in days }\end{array}$ & 1405.063 & 207.0759 & 1185 & 2202 \\
\hline \multirow{7}{*}{ Panel data } & $\begin{array}{l}\text { Private credit to private } \\
\text { firms over } \mathrm{GDP}^{\mathrm{b}}\end{array}$ & 211.58 & 114.37 & 27.96 & 703.27 \\
\hline & Real GDP per head $^{\mathrm{a}, \mathrm{e}}$ & 1966.37 & 441.44 & 644.67 & 3173.67 \\
\hline & $\begin{array}{l}\text { Sum of exports and imports } \\
\text { over GDP }\end{array}$ & 327.51 & 195.77 & 14.197 & 1181.67 \\
\hline & \begin{tabular}{lrr} 
Students & \multicolumn{2}{c}{ attending } \\
secondary school over & scolident population & \\
reside & \\
\end{tabular} & 45.08 & 8.01 & 29.48 & 65.10 \\
\hline & Crimes per head & 37.17 & 14.18 & 10.51 & 111.19 \\
\hline & $\begin{array}{l}\text { Un-weighted sum of the } \\
\text { length of first instance and } \\
\text { appeal civil trials in days }\end{array}$ & 792.27 & 174.62 & 385 & 1493 \\
\hline & $\begin{array}{l}\text { Weighted sum of the length } \\
\text { of first instance and appeal } \\
\text { civil trials in days }\end{array}$ & 1651.02 & 332.04 & 826.67 & 2554 \\
\hline
\end{tabular}

Notes:

${ }^{a}$ all real variables were deflated using the CPI of the main city of each province. The base year is $1985 .{ }^{b}$ billions of eurolire over millions of eurolire (by eurolire we mean that for the years after the introduction of the Euro we converted the value of the variables into Lire by using the official exchange rate of $€ 1=£$,1936.27). To obtain percentages, divide by $10{ }^{\mathrm{c}}$ number of students over resident population in thousands. To obtain percentages divide by $10 .{ }^{\mathrm{d}}$ number of crimes over resident population in thousands. To obtain the number of crimes per inhabitant, divide by $1000 .{ }^{\mathrm{e}}$ in ten thousands of eurolire. 
Table 2 - The effect of financial development on real economic growth in cross-section models Dependent variable: total real growth rate of GDP per head between 1986 and 2006

\begin{tabular}{|l|c|c|}
\hline & LSDV & 2SLSDV \\
\hline $\begin{array}{l}\text { Private credit to private firms over GDP in } \\
\mathbf{1 9 8 6}\end{array}$ & $7.36^{*}$ & $21.17^{*}$ \\
\hline t-stat. & $(2.23)$ & $(2.43)$ \\
\hline Sum of exports and imports over GDP in $1986^{\mathrm{a}}$ & 0.05 & -0.01 \\
\hline t-stat. & $(0.27)$ & $(-0.64)$ \\
\hline $\begin{array}{l}\text { Students attending secondary school over } \\
\text { resident population in 1986 }\end{array}$ & 0.65 & 0.42 \\
\hline t-stat. & $(1.36)$ & $(0.75)$ \\
\hline $\begin{array}{l}\text { Expenditure in finished public infrastructures } \\
\text { over GDP in 1986 }\end{array}$ & 0.22 & 0.37 \\
\hline t-stat. & $(1.22)$ & $(1.68)$ \\
\hline GDP per head in 1986 & $-39.88^{*}$ & $-44.48^{*}$ \\
\hline t-stat. & $(-3.83)$ & $(-3.63)$ \\
\hline Crimes per head in 1986 & 0.24 & 0.18 \\
\hline t-stat. & $(1.14)$ & $(0.75)$ \\
\hline Constant & 53.28 & 43.76 \\
\hline t-stat. & $(1.67)$ & $(1.18)$ \\
\hline Dummy Campania & -32.49 & -26.42 \\
\hline t-stat. & $(-1.80)$ & $(-1.25)$ \\
\hline Dummy Puglia & $-43.37 *$ & -30.20 \\
\hline t-stat. & $(-2.43)$ & $(-1.86)$ \\
\hline Dummy Sicilia & $-31.38^{*}$ & $-41.91^{*}$ \\
\hline t-stat. & $(-2.22)$ & $(-2.04)$ \\
\hline R $^{2}$ & 0.47 & 0.30 \\
\hline Moran's I & 0.55 & -0.73 \\
\hline Hausman test (p-value $)^{\mathrm{d}}$ & 0.00 & - \\
\hline Durbin - Wu - Hausman test (p-value $)^{\mathrm{e}}$ & - & 0.96 \\
\hline Instrumental variable F-test (p-value ${ }^{\mathrm{f}}$ & - & 0.00 \\
\hline Test for overidentifying restrictions (p-value) ${ }^{\mathrm{g}}$ & - & 0.74 \\
\hline Observations & 64 & 64 \\
\hline
\end{tabular}

Notes:

* denotes coefficients significant at the 5\% level. T-statistics are shown in parentheses. Instruments in the 2SLSDV regression in the second column include the weighted and the un-weighted sums of the length of first instance and appeal civil trials. ${ }^{a}$ exports and imports include only goods traded on international markets, since interregional trade is not registered. ${ }^{b}$ this dummy was significant when including a full set of regional dummies. So we chose to keep it in the model. ${ }^{\mathrm{c}}$ the null is no spatial correlation. ${ }^{d}$ the null is that the random-effects and the fixed-effects estimators are similar. If they are not similar, the latter will be preferred. ${ }^{\mathrm{e}}$ the null is no endogeneity in the comparison between the LSDV and the 2SLSDV estimators. ${ }^{f}$ the null is that the instruments are not correlated with the instrumented variables. ${ }^{g}$ the null is that instruments in excess with respect to instrumented variables are not correlated with 2SLS residuals. 
Table 3 - The effect of financial development on real economic growth - dynamic panel estimates (1986-2003)

Dependent variable: log of real GDP per capita.

Method: System-GMM.

Frequency of the data: three year averages.

\begin{tabular}{|c|c|c|c|}
\hline $\begin{array}{c}\text { Log(Private credit to } \\
\text { private firms over GDP) }\end{array}$ & $-3.40^{*}$ & Dummy Puglia & $-0.14^{*}$ \\
\hline t-stat. & $(-2.07)$ & t-stat. & $(-2.22)$ \\
\hline $\begin{array}{c}{[\log (\text { Private credit to }} \\
\text { private firms over GDP) }]^{2}\end{array}$ & $0.67^{*}$ & $\begin{array}{c}\text { Dummy for the years } \\
1992-1994\end{array}$ & $-0.08^{*}$ \\
\hline t-stat. & $(2.09)$ & t-stat. & $(-5.00)$ \\
\hline $\begin{array}{c}{[\log (\text { Private credit to }} \\
\text { private firms over GDP })]^{3}\end{array}$ & $-0.04 *$ & $\begin{array}{c}\text { Dummy for the years } \\
1995-1997\end{array}$ & $-0.04 *$ \\
\hline t-stat. & $(-2.11)$ & t-stat. & $(0.00)$ \\
\hline $\log (\text { real GDP per capita })_{t-1}$ & $0.81 *$ & $\begin{array}{c}\text { Test for first order } \\
\text { serial correlation }\left(\mathrm{p}^{-}\right. \\
\text {value })^{\mathrm{b}}\end{array}$ & 0.03 \\
\hline t-stat. & $(8.05)$ & $\begin{array}{l}\text { Test for second order } \\
\text { serial correlation }\left(p^{-}\right. \\
\text {value })^{c}\end{array}$ & 0.59 \\
\hline $\begin{array}{l}\text { Log(Students attending } \\
\text { secondary school over } \\
\text { resident population) }\end{array}$ & 0.11 & $\begin{array}{c}\text { Hansen test for } \\
\text { overident. restrictions } \\
(\mathrm{p} \text {-value })^{\mathrm{d}}\end{array}$ & 0.13 \\
\hline t-stat. & $(1.19)$ & Moran's I (p-value) $^{\mathrm{e}}$ & 0.88 \\
\hline $\begin{array}{l}\text { Log(Sum of exports and } \\
\text { imports over GDP) }\end{array}$ & $0.05^{*}$ & $\begin{array}{l}\text { Wald test for } \\
\text { poolability }^{\mathrm{f}}\end{array}$ & 0.51 \\
\hline t-stat. & $(2.79)$ & & \\
\hline $\log ($ Crimes per head $)$ & 0.37 & & \\
\hline t-stat. & $(0.45)$ & $\begin{array}{l}\text { Number of } \\
\text { instruments }\end{array}$ & 53 \\
\hline$[\log (\text { Crimes per head })]^{2}$ & -0.03 & Number of provinces & 77 \\
\hline t-stat. & $(-0.31)$ & Number of obs. & 359 \\
\hline
\end{tabular}

Notes: the instruments are past first differences and past levels of (Private credit to private firms over GDP $)_{t-1}$, logs of the weighted and un-weighted sums of the length of first instance and appeal civil trials. ${ }^{*}$ denotes coefficients significant at the $5 \%$ level. t-statistics are shown in parentheses. ${ }^{\text {a }}$ exports and imports include only goods traded on international markets as interregional trade is not registered. ${ }^{\mathrm{b}}$ the null is absence of first order serial correlation in the differenced residuals. Presence of first order serial correlation in the differenced residuals does not affect the validity of estimates. ${ }^{c}$ the null is absence of second order serial correlation in the differenced residuals. ${ }^{d}$ the null is that instruments in excess with respect to instrumented variables are not correlated with GMM residuals. We preferred the Hansen test to the Sargan test, because the former is robust to heteroskedasticity, and we do not have a large number of instruments when compared to the cross-sectional dimension of the dataset. ${ }^{\mathrm{e}}$ the null is no spatial correlation. ${ }^{\mathrm{f}}$ the null is that the coefficient of the financial indicator is the same across provinces belonging to the South, the North-East, the North West and the Centre of Italy, respectively. 


\section{QUADERNI DELLA FACOLTÀ}

I quaderni sono richiedibili (nell'edizione a stampa) alla Biblioteca universitaria di Lugano via G. Buffi 13 CH 6900 Lugano

e-mail: biblioteca@lu.unisi.ch

The working papers (printed version) may be obtained by contacting the Biblioteca universitaria di Lugano

via G. Buffi 13 CH 6900 Lugano

e-mail: biblioteca@lu.unisi.ch

Quaderno n. 98-01

P. Balestra, Efficient (and parsimonious) estimation of structural dynamic error component models

Quaderno n. 99-01

M. Filippini, Cost and scale efficiency in the nursing home sector : evidence from Switzerland

Quaderno n. 99-02

L. Bernardi, I sistemi tributari di oggi : da dove vengono e dove vanno

Quaderno n. 99-03

L.L. Pasinetti, Economic theory and technical progress

Quaderno n. 99-04

G. Barone-Adesi, K. Giannopoulos, L. Vosper, VaR without correlations for portfolios of derivative securities

Quaderno n. 99-05

G. Barone-Adesi, Y. Kim, Incomplete information and the closed-end fund discount

Quaderno n. 99-06

G. Barone-Adesi, W. Allegretto, E. Dinenis, G. Sorwar, Valuation of derivatives based on CKLS interest rate models

Quaderno n. 99-07

M. Filippini, R. Maggi, J. Mägerle, Skalenerträge und optimale Betriebsgrösse bei den schweizerische Privatbahnen

Quaderno n. 99-08

E. Ronchetti, F. Trojani, Robust inference with GMM estimators

Quaderno n. 99-09

G.P. Torricelli, I cambiamenti strutturali dello sviluppo urbano e regionale in Svizzera e nel Ticino sulla base dei dati dei censimenti federali delle aziende 1985, 1991 e 1995 
Quaderno n. 00-01

E. Barone, G. Barone-Adesi, R. Masera, Requisiti patrimoniali, adeguatezza del capitale e gestione del rischio

Quaderno n. 00-02

G. Barone-Adesi, Does volatility pay?

Quaderno n. 00-03

G. Barone-Adesi, Y. Kim, Incomplete information and the closed-end fund discount

Quaderno n. 00-04

R. Ineichen, Dadi, astragali e gli inizi del calcolo delle probabilità

Quaderno n. 00-05

W. Allegretto, G. Barone-Adesi, E. Dinenis, Y. Lin, G. Sorwar, A new approach to check the free boundary of single factor interest rate put option

Quaderno n. 00-06

G.D.Marangoni, The Leontief Model and Economic Theory

Quaderno n. 00-07

B. Antonioli, R, Fazioli, M. Filippini, Il servizio di igiene urbana italiano tra concorrenza e monopolio

Quaderno n. 00-08

L. Crivelli, M. Filippini, D. Lunati. Dimensione ottima degli ospedali in uno Stato federale

Quaderno n. 00-09

L. Buchli, M. Filippini, Estimating the benefits of low flow alleviation in rivers: the case of the Ticino River

Quaderno n. 00-10

L. Bernardi, Fiscalità pubblica centralizzata e federale: aspetti generali e il caso italiano attuale

Quaderno n. 00-11

M. Alderighi, R. Maggi, Adoption and use of new information technology

Quaderno n. 00-12

F. Rossera, The use of log-linear models in transport economics: the problem of commuters' choice of mode

Quaderno n. 01-01

M. Filippini, P. Prioni, The influence of ownership on the cost of bus service provision in Switzerland. An empirical illustration

Quaderno n. 01-02

B. Antonioli, M. Filippini, Optimal size in the waste collection sector

Quaderno n. 01-03

B. Schmitt, La double charge du service de la dette extérieure 
Quaderno n. 01-04

L. Crivelli, M. Filippini, D. Lunati, Regulation, ownership and efficiency in the Swiss nursing home industry

Quaderno n. 01-05

S. Banfi, L. Buchli, M. Filippini, Il valore ricreativo del fiume Ticino per i pescatori

Quaderno n. 01-06

L. Crivelli, M. Filippini, D. Lunati, Effizienz der Pflegeheime in der Schweiz

Quaderno n. 02-01

B. Antonioli, M. Filippini, The use of a variable cost function in the regulation of the Italian water industry

Quaderno n. 02-02

B. Antonioli, S. Banfi, M. Filippini, La deregolamentazione del mercato elettrico svizzero e implicazioni a breve termine per l'industria idroelettrica

Quaderno n. 02-03

M. Filippini, J. Wild, M. Kuenzle, Using stochastic frontier analysis for the access price regulation of electricity networks

Quaderno n. 02-04

G. Cassese, On the structure of finitely additive martingales

Quaderno n. 03-01

M. Filippini, M. Kuenzle, Analisi dell'efficienza di costo delle compagnie di bus italiane e svizzere

Quaderno n. 03-02

C. Cambini, M. Filippini, Competitive tendering and optimal size in the regional bus transportation industry

Quaderno n. 03-03

L. Crivelli, M. Filippini, Federalismo e sistema sanitario svizzero

Quaderno n. 03-04

L. Crivelli, M. Filippini, I. Mosca, Federalismo e spesa sanitaria regionale : analisi empirica per i Cantoni svizzeri

Quaderno n. 03-05

M. Farsi, M. Filippini, Regulation and measuring cost efficiency with panel data models : application to electricity distribution utilities

Quaderno n. 03-06

M. Farsi, M. Filippini, An empirical analysis of cost efficiency in non-profit and public nursing homes

Quaderno n. 03-07

F. Rossera, La distribuzione dei redditi e la loro imposizione fiscale : analisi dei dati fiscali svizzeri 
Quaderno n. 03-08

L. Crivelli, G. Domenighetti, M. Filippini, Federalism versus social citizenship : investigating the preference for equity in health care

Quaderno n. 03-09

M. Farsi, Changes in hospital quality after conversion in ownership status

Quaderno n. 03-10

G. Cozzi, O. Tarola, Mergers, innovations, and inequality

Quaderno n. 03-11

M. Farsi, M. Filippini, M. Kuenzle, Unobserved heterogeneity in stochastic cost frontier models : a comparative analysis

Quaderno n. 04-01

G. Cassese, An extension of conditional expectation to finitely additive measures

Quaderno n. 04-02

S. Demichelis, O. Tarola, The plant size problem and monopoly pricing

Quaderno n. 04-03

F. Rossera, Struttura dei salari 2000 : valutazioni in base all'inchiesta dell'Ufficio federale di statistica in Ticino

Quaderno n. 04-04

M. Filippini, M. Zola, Economies of scale and cost efficiency in the postal services : empirical evidence from Switzerland

Quaderno n. 04-05

F. Degeorge, F. Derrien, K.L. Womack, Quid pro quo in IPOs : why book-building is dominating auctions

Quaderno n. 04-06

M. Farsi, M. Filippini, W. Greene, Efficiency measurement in network industries : application to the Swiss railway companies

Quaderno n. 04-07

L. Crivelli, M. Filippini, I. Mosca, Federalism and regional health care expenditures : an empirical analysis for the Swiss cantons

Quaderno n. 04-08

S. Alberton, O. Gonzalez, Monitoring a trans-border labour market in view of liberalization: the case of Ticino

Quaderno n. 04-09

M. Filippini, G. Masiero, K. Moschetti, Regional differences in outpatient antibiotic consumption in Switzerland

Quaderno n. 04-10

A.S. Bergantino, S. Bolis, An adaptive conjoint analysis of freight service alternatives : evaluating the maritime option 
Quaderno n. 05-01

M. Farsi, M. Filippini, An analysis of efficiency and productivity in Swiss hospitals

Quaderno n. 05-02

M. Filippini, G. Masiero, K. Moschetti, Socioeconomic determinants of regional differences in outpatient antibiotic consumption : evidence from Switzerland

Quaderno n. 06-01

M. Farsi, L. Gitto, A statistical analysis of pain relief surgical operations

Quaderno n. 06-02

M. Farsi, G. Ridder, Estimating the out-of-hospital mortality rate using patient discharge data

Quaderno n. 06-03

S. Banfi, M. Farsi, M. Filippini, An empirical analysis of child care demand in Switzerland

Quaderno n. 06-04

L. Crivelli, M. Filippini, Regional public health care spending in Switzerland : an empirical analysis

Quaderno n. 06-05

M. Filippini, B. Lepori, Cost structure, economies of capacity utilization and scope in Swiss higher education institutions

Quaderno n. 06-06

M. Farsi, M. Filippini, Effects of ownership, subsidization and teaching activities on hospital costs in Switzerland

Quaderno n. 06-07

M. Filippini, G. Masiero, K. Moschetti, Small area variations and welfare loss in the use of antibiotics in the community

Quaderno n. 06-08

A. Tchipev, Intermediate products, specialization and the dynamics of wage inequality in the US

Quaderno n. 06-09

A. Tchipev, Technological change and outsourcing : competing or complementary explanations for the rising demand for skills during the 1980s?

Quaderno n. 07-01

M. Filippini, G. Masiero, K. Moschetti, Characteristics of demand for antibiotics in primary care : an almost ideal demand system approach

Quaderno n. 07-02

G. Masiero, M. Filippini, M. Ferech, H. Goossens, Determinants of outpatient antibiotic consumption in Europe : bacterial resistance and drug prescribers

Quaderno n. 07-03

R. Levaggi, F. Menoncin, Fiscal federalism, patient mobility and the soft budget constraint : a theoretical approach 
Quaderno n. 07-04

M. Farsi, The temporal variation of cost-efficiency in Switzerland's hospitals : an application of mixed models

Quaderno n. 08-01

M. Farsi, M. Filippini, D. Lunati, Economies of scale and efficiency measurement in Switzerland's nursing homes

Quaderno n. 08-02

A. Vaona, Inflation persistence, structural breaks and omitted variables : a critical view

Quaderno n. 08-03

A. Vaona, The sensitivity of non parametric misspecification tests to disturbance autocorrelation

Quaderno n. 08-04

A. Vaona, STATA tip : a quick trick to perform a Roy-Zellner test for poolability in STATA

Quaderno n. 08-05

A. Vaona, R. Patuelli, New empirical evidence on local financial development and growth 